\title{
THE MODELLING OF TRANSFER PROCESSES OF THE OIL POLLUTION WITH CALCULATION OF LANGMUIR CIRCULATION.
}

\author{
Mihail V.Romanov \\ State Technical University, Russia \\ Nikolay I. Minyaev \\ Russian State Hydrometeorological University, Russia
}

\begin{abstract}
In the present work the mechanisms of formation extended spots or strips of oil have been investigated with account of their physics-chemical characteristics under influence of dynamic particularities of top subhomogenious layer (in particular, circulation of Langmuir (LC)).
\end{abstract}

KEYWORDS: oil pollution; mathematical model; Langmuir circulation; windrows.

\section{INTRODUCTION}

The oil and oil-products are most widespread and dangerous pollutants for sea. The pollution of sea by oil is caused by many reasons: by a drain of the polluted river waters, by accidents of ships (especially tankers), by losses at extraction process and by entering with deposits from atmosphere, etc.

The greatest concentration of petroleum in reservoirs are located in thin subsurface microlayer, which is a collector of all polluting substances. Oil films essentially influence many properties of surface of the unit water - air and break warm -, moisture -, gas exchange between ocean and atmosphere, decrease penetration of light and speed of photosynthesis processes.

The oil hydrocarbons have toxicity and ability to concentrate in water organisms on increase trophic level in sea ecosystems. Oil influences on structure of sea organisms communities and leads to decreasing of ecosystem stability. It could be shown in change of ratio 
of kinds and sorts, in decreasing of kind variety, in heavy development of specific microflora. which is toxic for many hydrobionts.

Oil slicks usually have circle forms, however they can have form of spreads extended on a wind direction. It is connected with convergention of surface currents (Grose and Mattson, 1977). The presence of oil as separate strips or spots testifies about non-uniform distribution of these polluting substances. It is possible to explain by horizontal heterogeneity of a field of speed of current created by different reasons (by internal waves, by circulation of Langmuir, by convection, etc.) on surface.

The winner of the Nobel prize of 1932 in the field of physical chemistry Irving Langmuir has paid attention to rather narrow strips of foam on a reservoir surface. These strips are disposited along a direction of wind near the surface and become appreciable at achievement by wind equal $3-5 \mathrm{~m} / \mathrm{sec}$. Foam, seaweed, fragments of macrophytes, etc. is pulled in the strips. I.Langmuir has carried out a series of original experiments and has given a qualitative description of the phenomenon (Langmuir, 1938), which may be reduced to following:

1) Parallel to wind direction wind of strips mark helicoidal circulating coherent structures arising in the top layer of a reservoir. Two next strips limit circulating cell of Langmuir;

2 ) the right and left-hand whirlwinds with longitudinal axes arise in the cells. At the surface particles are converging in strips and diverging between strips;

3 ) in sells the whirlwinds are asymmetric, as descending components of speed are more than ascending. The descending components are great and have the same value as horizontal components;

4) a particle in LC have a component of speed in a wind direction $U$, alongside with cross rotary movement. In spreads of convection the value $\mathrm{U}$ is higher, than between strips;

5 ) on seen, wind is basic power source of these movements of water and determine their basic parameters;

6) LC lead to intensive horizontal and vertical redistribution of weight, heat and impulse. It is cause of original physical and chemical - biological regime of the top layer of a reservoir.

Just last feature explains interest to research of LC. Subsequent investigations in nature have confirmed the qualitative scheme of the phenomenon offered by I.Langmuir and have given new quantitative estimations for LC.

\section{OUR INVESTIGATIONS AND CONCLUSION}

The researchers of last years (Scott et al., 1969; Ryanjin and Mironov, 1985) have shown that LC is not unusual occurrence, as it was considered earlier. The frequency of generation LC or their repeatability essentially depends on wind speed Va. It was definitely, that the wind speed $\mathrm{Vcr}=3 \sim 5 \mathrm{~m} / \mathrm{sec}$ is need for generation of LC. The common probability of LC occurrence is same to lake and sea conditions. At increase of wind speed the probability of LC occurrence grows also and at $\mathrm{Va}>10 \mathrm{~m} / \mathrm{sec}$ achieves 1 .

At the very strong winds ( $\mathrm{Va}>15 \mathrm{~m} / \mathrm{sec}$ ) $\mathrm{CL}$ isn't observed (the supervision of LC are absent). It is known these speeds are characteristic for storm situations with the special regime of energy exchange on boundary of water - air. In this case it is possible to assume existence of the following regimes of behavior of the top layer of reservoir in relation to LC:

a) praecritical at $\mathrm{Va}<\mathrm{Vcr}=3 \sim 5 \mathrm{~m} / \mathrm{sec}$, when the generation of LC does not occur;

b) critical at $\mathrm{Vcr}<\mathrm{Va}<15 \mathrm{~m} / \mathrm{sec}$, when there is an active generation of LC; 
c) supercritical or storm at $\mathrm{Va}>15 \mathrm{~m} / \mathrm{sec}$, when the generation of LC does not occur, and if it existed before than collapse.

In presented paper the attempt of modeling of oil distribution on a surface of the Baltic sea is made at various under various hydrometeorological conditions with calculation of LC. On the basis of experimental data of S.V.Ryanjin and data published in the world literature the following statistical dependencies are received:

1) the distance between strips of convergention (L) on a surface of the sea. The data on distances between strips are rather various and consequently all data were normated on a wind speed:

$\mathbf{L n}=\mathbf{L} * \mathbf{g} / \mathbf{V a}^{2}$

here $\mathrm{Ln}$ - dimensionless distance between strips of convergention; $\mathrm{g}$ - acceleration of free fall, $\mathrm{m} / \mathrm{sec}^{2}: \mathrm{Va}$ - speed of wind near the surface, $\mathrm{m} / \mathrm{sec}$.

Coefficient of linear pair correlation between $\mathrm{Ln}$ and $\mathrm{Va}$ has appeared $\mathrm{r}=-0.92$ and following регрессионная dependence is found:

$\operatorname{Ln}=8.08$ * $\exp (-0.24 * \mathrm{Va})$

2) The speed in LC on a direction along wind ( $\mathrm{Uw}$ ) depends from a wind speed and it has coefficient of linear pair correlation $r=0.73$. Uw may be determined on the equation:

$\mathrm{Uw}=0.66 * \mathrm{Va}^{1.58}$

3) The speed in LC on a direction perpendicular wind ( $\mathrm{Vw})$ may be determined on the equation (coefficient of linear pair correlation $r=0.73$ ):

$\mathrm{Vw}=0.06 * \mathrm{Va}^{1.99}$

The results of calculation of LC parameters at various wind speeds are submitted in Table 1.

The oil, getting in ocean, is distributed in it under the complex laws. Schematically this process can be presented by following image. At overflow on water surface (for example, at accident of a tanker) oil spreads by gravity in the beginning. When a layer of oil becomes more thick. the forces of viscosity and superficial tension becomes the most important in forces balance. These forces depend on properties of oil, which can essentially change in spreading process. For example, density and viscosity of oil usually grow owing to evaporation and dissolution in water. As a result of it the moment, when the superficial tension will change a mark can come and spreading of oil stain under action of force of surface tension to stop. In the further stain can be increased under action of mechanical forces of driven water masses, i.e. message itself similarly to a stain of a usual passive impurity.

In spreading of oil on a sea surface usually allocate three phases (Ozmidov, 1989): inertial, gravity-viscous and phase of surface tension. The time of influence of inertia can be received by calculating the appropriate Reinolds' number. According to Fay (Fay, 1969):

$\operatorname{Re}=h /(v t)^{1 / 2}$

here $\mathrm{h}$ - thickness of a oil film (cm); v - kinematic viscosity of water $\left(\mathrm{cm}^{2} / \mathrm{sec}\right)$; t- time after flood (sec).

Equating the equation (5) to 1, we receive:

$t_{m}^{3 / 2}=0.5[V /(2 \pi g v \lambda)]^{1 / 2}$

and appropriate maximal radius of a round stain: 
$\operatorname{Roe}=\left[0.637(2 \lambda g \pi V)^{1 / 2} * t_{m}\right]^{1 / 2}$

(7),

here $\lambda=\rho_{\mathrm{w}}-\rho / \rho_{\mathrm{w}} ; \rho_{\mathrm{w}}$ and $\rho$ - density of water and oil accordingly $\left(\mathrm{g} / \mathrm{cm}^{3}\right) ; \mathrm{V}=\pi \mathrm{hR} \mathrm{R}^{2}$ characteristic volume of spreading oil $\left(\mathrm{cm}^{3}\right) ; \mathrm{t}_{\mathrm{m}}$ - time of influence of inertia forces $(\mathrm{sec})$.

The investigations of last years have shown, that the first and second phase of oil spreading is usual influence during relatively small interval of time in comparison with total time of spreading. Speed of spreading in the phase of surface tension may be determined on following formula:

$\mathbf{R}=\mathbf{C}\left[\sigma^{2} * \mathbf{t}^{3} / \rho_{\mathrm{w}}{ }^{2} * v\right]^{1 / 4}$

here $\mathrm{R}$ - radius of a round oil stain in thirds to phase of spreading $(\mathrm{cm}) ; \mathrm{C}$ - a constant $(\mathrm{C} \approx 1) ; \sigma=$ $\sigma_{1}-\sigma_{2}-\sigma_{3} ; \sigma_{1}, \sigma_{2}, \sigma_{3}$ - surface tension on boundaries of water - air, oil - water, oil - air accordingly (din/cm).

The approbation of model was carried out on an example of the Baltic sea at emergency overflow of oil of volume $\mathrm{V}=1.6^{*} 10^{6} \mathrm{~cm}{ }^{3}$. The physical characteristics of oil and oil products submitted in Table 2. An emergency flood Libyan and Kuwait oil and also black oil $\mathrm{F}$ at various wind speeds $4 ; 6 ; 8$ and $10 \mathrm{~m} / \mathrm{sec}$, temperature of water $15^{\circ} \mathrm{C}$, density of water $1,004949 \mathrm{~g} / \mathrm{cm}^{3}$, kinematic viscosity $0,012 \mathrm{cmo}^{2} / \mathrm{sec}$ has been considered. In this model the assumption is accepted that the distribution of oil stain occurs by means of speed of spreading and speeds of water currents in whirlwinds of Langmuir, namely $U$ and $\mathrm{V}$ components. $\mathrm{U}$ is the component of speed of LC extends oil stain along wind direction, and $\mathrm{V}$ is the component for formation of windrows on sea surface. It is possible to allocate the following slick forms under the relation $\mathrm{U}$ and $\mathrm{V}$ components of speed of LC to speed of spreading of a round oil stain:

1) $\mathrm{Vro}=\mathrm{R} / \mathrm{t}>\mathrm{U}>\mathrm{V}$ - the oil stain has the round form. In this case LC stops and does not influence on distribution of oil on a sea surface.

2) $\mathrm{U}>\mathrm{Vr}>\mathrm{V}$ - the oil stain is extended on a wind direction and gets the form of an ellipse with axes $a \sigma(U+V r) * t$ and $b=2 R$. The thickness of the given stain is determined as:

$\mathbf{h}=\mathbf{V} / \pi^{\star} \mathbf{k}^{\star} \mathbf{R}$

here $k=a / 2$ and $R-$ is half-axis of an ellipse of a oil stain, $\mathrm{cm}$.

3) $U>V>V r-$ the oil stain has form of windrows with thickness:

$\mathbf{h}=\mathbf{V} / \mathbf{a} * \mathbf{L}$

here $\mathrm{L}$ - distance between strips of convergention, $\mathrm{cm}$.

The results of calculation of oil stain spreading on a surface of the Baltic Sea in view of inertia and surface tension forces are submitted in Table 4 (LC is absent). And the results of calculation of oil stain spreading at presence LC are shown in Table 5. 
Table 1. The parameters of LC at different wind speeds for Baltic Sea.

\begin{tabular}{|c|c|c|c|}
\hline $\begin{array}{c}\text { Wind } \\
\text { speed, } \\
\mathbf{m} / \mathbf{s e c}\end{array}$ & $\begin{array}{c}\text { Distance between strips } \\
\text { of convergention } \mathbf{L}, \mathbf{m}\end{array}$ & $\mathbf{V}, \mathbf{c m} / \mathbf{s e c}$ \\
\hline & & $\mathbf{U}, \mathbf{c m} / \mathbf{s e c}$ & 1,0 \\
\hline 4 & 5 & 5,8 & 2,1 \\
\hline 6 & 7 & 11,1 & 3,8 \\
\hline 8 & 8 & 17,4 & 5,9 \\
\hline 10 & 8 & 24,7 & \\
\hline
\end{tabular}

Table 2. The physical characteristics of oil (oil products) used in the model.

\begin{tabular}{|c|c|c|c|}
\hline Kind of oil & $\begin{array}{c}\text { Density } \rho, \\
\mathbf{g} / \mathbf{c m}^{\mathbf{3}}\end{array}$ & $\begin{array}{c}\text { Surface tension } \sigma, \\
\mathbf{d i n} / \mathbf{c m}\end{array}$ & $\lambda$ \\
\hline Libya & 0,829 & 27 & 0,1751 \\
\hline Kuwait & 0,869 & 17 & 0,1353 \\
\hline Black oil F & 0,904 & 14 & 0,1005 \\
\hline
\end{tabular}

Table 3. Time of influence of inertia forces and maximal value of radius of round oil stain at the first phase of spreading.

\begin{tabular}{|c|c|c|c|c|}
\hline Kind of oil & \multicolumn{2}{|c|}{$V=1, \mathbf{1}^{*} \mathbf{1 0}^{\mathbf{6}} \mathbf{c m}^{\mathbf{3}}$} & \multicolumn{2}{c|}{$\mathrm{V}=1, \mathbf{8} * \mathbf{1 0}^{\mathbf{1 0}} \mathbf{c m}^{\mathbf{3}}$} \\
\hline & $\mathbf{t}_{\mathbf{m}}, \mathbf{s e c}$ & $\mathbf{R}_{\mathbf{0}}, \mathbf{m}$ & $\mathbf{t}_{\mathbf{m}}, \mathbf{s e c}$ & $\mathbf{R}_{\mathbf{0}}, \mathbf{m}$ \\
\hline Libya & 314 & 16,2 & 3264 & 302,7 \\
\hline Kuwait & 342 & 15,9 & 3557 & 296,2 \\
\hline Black oil F & 378 & 15,5 & 3927 & 289 \\
\hline
\end{tabular}


Table 4. Spres dimz of round oil stain on a surface of the Baltic Sea at absence of LC.

\begin{tabular}{|c|c|c|c|c|}
\hline $\begin{array}{l}\text { Kind } \\
\text { of oil }\end{array}$ & $\begin{array}{c}\text { Time after } \\
\text { overflow, } \\
\text { sec }\end{array}$ & $\begin{array}{l}\text { Radius of } \\
\text { stain } R, m\end{array}$ & $\begin{array}{l}\text { Speed of } \\
\text { spreading, } \\
\text { cm/sec }\end{array}$ & $\begin{array}{c}\text { Thickness h, } \\
\text { cm }\end{array}$ \\
\hline \multirow{4}{*}{$\begin{array}{c}\text { Liby } \\
\text { a }\end{array}$} & 2400 & 70 & 2,9 & 0,01 \\
\hline & 3600 & 89,2 & 2,5 & 0,006 \\
\hline & 10800 & 182,5 & 1,7 & 0,002 \\
\hline & 18000 & 260,2 & 1,4 & 0,0008 \\
\hline \multirow{4}{*}{$\begin{array}{l}\text { Kuw } \\
\text { ait }\end{array}$} & 2400 & 58,6 & 2,4 & 0,02 \\
\hline & 3600 & 73,8 & 2,1 & 0,009 \\
\hline & 10800 & 147,9 & 1,4 & 0,002 \\
\hline & 18000 & 209,5 & 1,2 & 0,001 \\
\hline \multirow{5}{*}{$\begin{array}{c}\text { Blac } \\
\text { k oil } \\
\text { F }\end{array}$} & 2400 & 54,3 & 2,3 & 0,02 \\
\hline & & & & \\
\hline & 3600 & 68,3 & 1,9 & 0,01 \\
\hline & 10800 & 135,3 & 1,3 & 0,003 \\
\hline & 18000 & 191,2 & 1,1 & 0,001 \\
\hline
\end{tabular}

As a result of calculation (Table 4-5) the important role of LC in distribution of oil on a sea surface is visible. The role of LC in distribution of oil grows at increase of a wind speed. Under action of a wind (namely, LC) the oil stain is extended along convergention spreads getting thus the form of an ellipse or windrows (Table 5). At small wind speed 4 $\mathrm{m} / \mathrm{sec}$ the oil stain has the form of an ellipse for all period of calculation (5 hours). It is necessary to note, that the speed of spreading in length of a stain is various for different kinds of oil. Apparently it is connected to a surface tension of oil film. When this parameter become less the spreading of a stain both in length and in width towards the wind decreases. 
Table 5. Spreading of oil slicks on a surface of the Baltic Sea with the account of LC.

\begin{tabular}{|c|c|c|c|c|}
\hline \multirow{2}{*}{$\begin{array}{l}\text { Kind } \\
\text { of oil }\end{array}$} & \multirow{2}{*}{$\begin{array}{l}\text { Time after } \\
\text { overflow, } \\
\text { sec }\end{array}$} & \multicolumn{2}{|c|}{ Axis of distribution } & \multirow{2}{*}{$\begin{array}{c}\text { Form of a } \\
\text { stain }\end{array}$} \\
\hline & & $\begin{array}{c}\text { along } \\
\text { strips, m }\end{array}$ & $\begin{array}{c}\text { across } \\
\text { strips, m }\end{array}$ & \\
\hline \multicolumn{5}{|c|}{ Wind speed $4 \mathrm{~m} / \mathrm{sec}$} \\
\hline Libya & 18000 & 1296 & 260,2 & an ellipse \\
\hline $\begin{array}{c}\text { Kuwai } \\
\mathrm{t}\end{array}$ & 18000 & 1260 & 209,5 & an ellipse \\
\hline $\begin{array}{l}\text { Black } \\
\text { oil F }\end{array}$ & 18000 & 1242 & 191,2 & an ellipse \\
\hline \multicolumn{5}{|c|}{ Wind speed $6 \mathrm{~m} / \mathrm{sec}$} \\
\hline Libya & 3600 & 489,6 & 89,2 & an ellipse \\
\hline & 10800 & 1382,4 & 7 & windrows \\
\hline \multirow{2}{*}{$\begin{array}{c}\text { Kuwai } \\
t\end{array}$} & 2400 & 324 & 56,8 & an ellipse \\
\hline & 3600 & 475,2 & 7 & windrows \\
\hline \multirow{2}{*}{$\begin{array}{l}\text { Black } \\
\text { oil F }\end{array}$} & 2400 & 321,6 & 54,3 & an ellipse \\
\hline & 3600 & 468 & 7 & windrows \\
\hline \multicolumn{5}{|c|}{ Wind speed $8 \mathrm{~m} / \mathrm{sec}$} \\
\hline Libya & 2400 & 487,2 & 8 & windrows \\
\hline & 18000 & 3384 & 8 & windrows \\
\hline $\begin{array}{c}\text { Kuwai } \\
\mathrm{t}\end{array}$ & 18000 & 3348 & 8 & windrows \\
\hline $\begin{array}{c}\text { Black } \\
\text { oil F }\end{array}$ & 18000 & 3330 & 8 & windrows \\
\hline
\end{tabular}


While strengthening of wind the oil stain is extended in the form of a strip with a direction along strips of convergation. For example, at wind speed $6 \mathrm{~m} / \mathrm{sec}$ for the Libyan petroleum during the first hour after flood the oil stain has the form of an ellipse, in three hours after flood the stain is broken off in strips in zones of divergation of LC. The distance between oil strips is approximately equal to distance between strips of convergation. Kaweit oil and the black Oil $\mathrm{F}$ is broken off in strips in one hour after emergency flood (for volume of overflow 1,6*106 $\mathrm{cm}^{3}$ ). At wind speed $8 \mathrm{~m} / \mathrm{sec}$ and more the oil stain gets the form of a strip almost immediately after overflow. It is necessary to note that the windrows are changed its direction very quickly (15-25 minutes) at change of wind direction. The angle of deviation of windrows from a wind direction is equal approximately $15^{\circ}$.

Our investigations have considerable practical significance, because we can organize the effective action of special ships for collection of oil if we have a relative simple mathematical model for operation prognosis of oil distribution during influence of LC. Now we work on creation of a similar model.

\section{List of references:}

1. Fay I.A. (1969). The spread of oil slicks on calm sea. In: Oil on the sea. London, pp.5364.

2. Grose P.L., Mattson J.S. (1990). The Argo Merchant Oil Spill. A preliminary scientific report. -NOAA Special Report, U.S. Department of Commerce.

3. Langmuir I. (1938). Surface motion of water induced by wind. In: Science, Vol.87, № 2250, pp.119-123. DOI: https://doi.org/10.1126/science.87.2250.119

4. Ozmidov R.V. (1989). Diffusion of impurities in ocean. Leningrad, Hydrometeoizdat. 5. Ryanjin S.V., Mironov D.V. (1985). On repeatability and critical conditions of occurrence of Langmuir circulation. In: Izvestiya AN USSR, FAO, vol. 21, № 2, pp.140190.

6. Scott J.T. et. al. (1969) On the mechanism of Langmuir circulation and their role in epilimnion mixing. In: Limnol. Oceanogr., Vol.14, № 14, pp. 493-503. 